\title{
Analisis Miskonsepsi Siswa pada Bilangan Berpangkat
}

\author{
Puji Nurkamilah"1, dan Ekasatya Aldila Afriansyah ${ }^{2 *}$ \\ ${ }^{1}$ Program Studi Pendidikan Matematika, SDIT Bina Insan Qur'ani \\ Jalan Raya Bandrek, RT.2/RW.6, Padasuka, Kabupaten Garut, Jawa Barat, Indonesia \\ pujinurkamilah346@gmail.com \\ ${ }^{2}$ Program Studi Pendidikan Matematika, IPI Garut \\ Jalan Terusan Pahlawan No 32 Sukagalih, Garut, Jawa Barat, Indonesia \\ ekasatyafriansyah@institutpendidikan.ac.id
}

Artikel diterima: 18-04-2020, direvisi: 20-09-2020, diterbitkan: 30-01-2021

\begin{abstract}
Abstrak
Beberapa hasil penelitian terdahulu menunjukkan adanya miskonsepsi yang dialami siswa dalam menyelesaikan soal bilangan berpangkat. Penelitian ini bertujuan untuk menganalisis bentuk miskonsepsi yang sering dilakukan siswa dalam menyelesaikan soal bilangan berpangkat. Adapun jenis penelitian yang digunakan dalam penelitian ini adalah penelitian kualitatif. Hal ini bertujuan untuk mendapatkan pemahaman yang mendalam mengenai bentuk miskonsepsi yang dialami siswa dalam menyelesaikan soal yang berkaitan dengan bilangan berpangkat. Penelitian dilaksanakan di MTsN 2 Garut dengan sumber data dalam penelitian ini adalah 32 siswa, dengan fokus hanya pada tiga orang siswa saja, masing-masing siswa berkemampuan tinggi, siswa berkemampuan sedang dan siswa berkemampuan rendah dalam pembelajaran matematika. Instrumen dalam penelitian ini berupa tes, disertai wawancara. Dari hasil penelitian diperoleh bahwa pada materi bilangan berpangkat ini, terdapat siswa yang mengalami miskonsepsi generalisasi, miskonsepsi notasi, miskonsepsi penspesialisasian, dan miskonsepsi bahasa. Kata Kunci: bilangan berpangkat, penelitian kualitatif, miskonsepsi.
\end{abstract}

\section{Analysis of Students' Misconceptions on Exponential Numbers}

\begin{abstract}
Some of the results of previous research showed that there were misconceptions experienced by students in solving exponential questions. This study aims to analyze the form of misconceptions that students often do in solving exponential questions. The type of research used in this research is qualitative research. This aims to gain a deep understanding of the form of misconceptions experienced by students in solving questions related to exponents. The research was conducted at MTsN 2 Garut with data sources in this study were 32 students, with a focus on only three students, each student with high ability, students with the medium ability, and students with low abilities in learning mathematics. The instrument in this study was a test, accompanied by an interview. From the research results, it was found that in this exponential number material, there were students who experienced misconception of generalization, the misconception of notation, the misconception of specialization, and misconception of language.

Keywords: exponential words, qualitative research, misconception.
\end{abstract}




\section{Pendahuluan}

Matematika adalah cabang dari segala ilmu hitung, hingga akhirnya matematika disebut sebagai The Queen of Science (ratunya ilmu). Karena begitu pentingnya matematika maka setiap orang seharusnya mempelajari dan memahami konsep pembelajaran matematika sejak dini (Afriansyah, 2012). Sehingga, salah satu aspek pembelajaran yang mutlak harus didapatkan dan dikuasai siswa adalah pemahaman konsep (Sari \& Afriansyah, 2020). Pentingnya pemahaman konsep matematika terlihat dalam tujuan pembelajaran matematika menurut Permendiknas no 22 tahun 2006 yaitu memahami konsep matematika, menjelaskan keterkaitan antar konsep dan mengaplikasikan konsep atau algoritma secara luwes, akurat, efisien dan tepat dalam pemecahan masalah. Namun, sifat abstrak dari matematika menyebabkan banyak siswa mengalami kesulitan dalam memahami konsep-konsep matematika. Kesulitan siswa dalam mempelajari matematika menurut Supatmono (Afriansyah \& Dahlan, 2017; Siagian \& Surya, 2018) dikarenakan siswa tidak membangun sendiri tentang pengetahuan konsep-konsep matematika tetapi cenderung menghafalkan konsep-konsep matematika tanpa mengetahui makna yang terkandung pada konsep tersebut. Menurut Utami (2017) dan Susanti (2020), salah satu hambatan siswa dalam memahami suatu konsep dalam matematika adalah konsep-konsep yang disampaikan oleh guru tidak dapat diterima dengan baik oleh siswa atau sering disebut dengan miskonsepsi.

Miskonsepsi dapat berbentuk kesalahan konsep awal (Latifah, Wakhyudin, \& Cahyadi, 2020), kesalahan hubungan yang tidak benar antara konsepkonsep, gagasan atau pandangan yang salah. Menurut Ikram, Suharto, \& Setiawani (2018), siswa dikatakan mengalami miskonsepsi apabila kesalahankesalahan yang dilakukan siswa itu berulang dan setelah digali lebih dalam siswa itu mengalami kesalahpahaman dalam memahami dan menafsirkan serta mengimplementasikan suatu konsep. Miskonsepsi ini dapat terjadi dalam pembelajaran matematika diantaranya pada materi bilangan berpangkat. Hal ini sejalan dengan hasil penelitian Febriyani (2015) yang menunjukkan adanya kesalahan dalam konsep bilangan berpangkat yang dialami oleh siswa. Ada beberapa fakta yang didapatkan bahwa banyak ditemukan miskonsepsi yang dilakukan siswa dalam menyelesaikan soalsoal bilangan berpangkat, contohnya, ketika siswa diberikan soal seperti berikut: "Hitunglah nilai dari $50^{5} \div 5^{5}$ !". Beberapa siswa menjawab bahwa $50^{5} \div 5^{5}=10$ (Pinahayu, 2015). Selanjutnya, Pratama (2017) menyatakan bahwa adanya kesalahan yang dilakukan siswa dalam menyelesaikan soal bentuk pangkat, akar dan logaritma terdiri dari kesalahan konseptual dan kesalahan prosedural, dan masih banyak lagi penelitian-penelitian 
yang menemukan adanya miskonsepsi yang dialami siswa pada materi bilangan berpangkat.

Learn (Yanti, 2017) mengungkapkan bahwa miskonsepsi dikategorikan ke dalam empat bentuk miskonsepsi yaitu: miskonsepsi pengertian huruf, miskonsepsi notasi, miskonsepsi penggeneralisasian, dan miskonsepsi pengaplikasian aturan. Sementara itu, Nurtasari, Jamiah, \& Suratman (2017) mengungkapkan bahwa miskonsepsi yang dialami siswa diantaranya miskonsepsi penggeneralisasian, miskonsepsi penspesialisasian dan miskonsepsi notasi. Sedangkan menurut Cangelosi (Wahyuni, Yusmin, \& Suratman, 2016), miskonsepsi juga terjadi pada materi eksponen yaitu miskonsepsi bahasa, miskonsepsi pengelompokan dan miskonsepsi notasi. Berdasarkan teori jenis miskonsepsi tersebut, maka jenis miskonsepsi yang di ambil dalam penelitian ini adalah miskonsepsi penggeneralisasian. miskonsepsi notasi, miskonsepsi penspesialisasian dan miskonsepsi bahasa.

Asholock (Nurtasari, Jamiah, \& Suratman, 2017) menyatakan bahwa miskonsepsi pengeneralisasian merupakan bentuk miskonsepsi yang didasari atas pernyataan umum yang berlebih terhadap sebuah alasan, dan siswa langsung menarik kesimpulan sebelum memiliki informasi yang lebih untuk menyimpulkan. Learn (Nurtasari, Jamiah, \& Suratman, 2017) yang menyatakan bahwa miskonsepsi notasi adalah pemahaman yang keliru terhadap sebuah notasi yang dapat berupa pemahaman yang berbeda terhadap sebuah notasi, penggunaan notasi yang keliru, dan mengabaikan sebuah notasi. Miskonsepsi Penspesialisasian menurut Asholock (Nurtasari, Jamiah, \& Suratman, 2017) merupakan bentuk miskonsepsi yang didasari atas spesialisasi yang berlebihan selama proses pembelajaran. Miskonsepsi Bahasa menurut Wahyuni, Yusmin, \& Suratman (2016) dapat berupa kesalahan dalam mengubah informasi ke dalam bahasa matematika.

\section{Metode}

Penelitian ini merupakan penelitian kualitatif deskriptif (Sugiyono, 2018) dengan sumber partisipasinya adalah 32 siswa dari kelas IX-I MTsN 2 Garut, tetapi fokus penelitian hanya pada tiga siswa saja. Waktu penelitian dilakukan mulai dari bulan November 2019 sampai Februari 2020 (lihat Tabel 1).

Tabel 1. Jadwal Penelitian

\begin{tabular}{|c|c|c|}
\hline Tahap & Waktu & Kegiatan \\
\hline 1 & $\begin{array}{c}\text { Sabtu, } 2 \\
\text { November } \\
2019\end{array}$ & $\begin{array}{c}\text { Bertemu dengan } \\
\text { kesiswaan MTsN } 2 \\
\text { Garut untuk meminta } \\
\text { izin penelitian, dan } \\
\text { bertemu dengan guru } \\
\text { mata pelajaran } \\
\text { Matematika untuk } \\
\text { meminta izin } \\
\text { penelitian dan mencari } \\
\text { tahu kondisi siswa yang } \\
\text { akan menjadi subjek } \\
\text { penelitian. }\end{array}$ \\
\hline 2 & $\begin{array}{c}\text { Rabu, } 13 \\
\text { November }\end{array}$ & $\begin{array}{l}\text { Uji coba instrumen di } \\
\text { kelas IX-H MTsN } 2\end{array}$ \\
\hline
\end{tabular}




\begin{tabular}{|ccc|}
\hline \multicolumn{2}{|c|}{2019} & Garut \\
\hline 3 & $\begin{array}{c}\text { Jum'at, 22 } \\
\text { November } \\
2019\end{array}$ & $\begin{array}{c}\text { Tes di kelas IX-I MTsN 2 } \\
\text { Garut }\end{array}$ \\
\hline 4 & Sabtu, 1 & Melakukan wawancara \\
& Februari & dengan siswa kelas IX-I \\
& di Perpustakaan MTs \\
& & Negeri 2 Garut \\
\hline Pengumpulan & data & dilakukan dengan
\end{tabular}

memberikan tes dengan soal tes yang bentuknya sama. Karena, menurut Ikram, Suharto, \& Setiawani (2018), siswa dikatakan mengalami miskonsepsi apabila kesalahan-kesalahan yang dilakukan siswa itu berulang. Tes yang digunakan dalam penelitian ini berupa soal bentuk uraian (lihat Gambar 1).

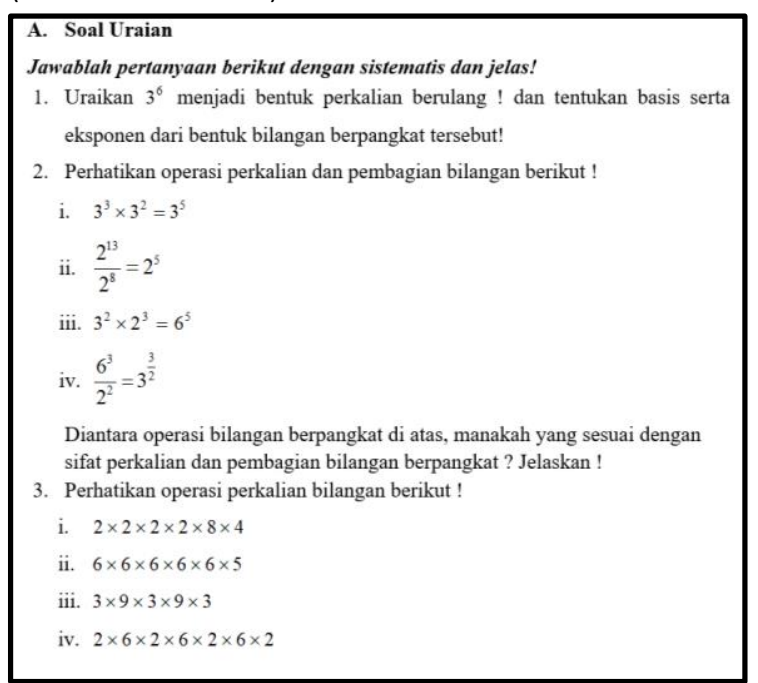

Teknik pengumpulan data pada penelitian ini dilakukan dengan observasi (pengamatan), tes, dan interview (wawancara). Observasi yang digunakan dalam penelitian ini yaitu observasi terus terang dan tersamar. Jadi, mereka yang diteliti mengetahui sejak awal sampai akhir tentang aktivitas peneliti. Tetapi dalam suatu saat peneliti juga tidak terus terang atau tersamar dalam observasi. Tes digunakan untuk melihat sejauh mana penguasaan konsep siswa pada materi bilangan berpangkat dan untuk mengetahui penguasaan, kesulitan, dan miskonsepsi siswa dalam menyelesaian soal-soal yang berkaitan dengan materi bilangan berpangkat. Peneliti menggunakan wawancara semiterstruktur agar dalam wawancaranya peneliti lebih bebas dalam menemukan permasalahan secara lebih terbuka, dimana siswa yang diwawancara diminta penjelasan dari jawaban tertulisnya.

Teknik analisis data yang digunakan yaitu teknik analisis model Miles and Huberman yaitu data reduction (Reduksi Data), data display (Penyajian Data), dan conclusion drawing/verification (Verifikasi). Tahapan reduksi data dalam penelitian ini adalah mengklasifikasikan jawaban siswa yang benar dan yang salah. Untuk jawaban siswa yang salah dilakukan analisis lanjutan yang selanjutnya diklasifikasikasikan pada kesalahan kerena tidak menjawab, kesalahan karena miskonsepsi generalisasi, kesalahan karena miskonsepsi penspesialisasian, kesalahan karena miskonsepsi notasi dan kesalahan karena miskonsepsi bahasa. Penyajian data dalam penelitian ini berupa persentase jawaban siswa berdasarkan data yang telah di klasifikasi pada tahap sebelumnya. Hal ini bertujuan untuk melihat banyaknya siswa yang melakukan miskonsepsi dalam menyelesaikan soal berkaitan dengan bilangan berpangkat. Pada tahap kesimpulan, didasarkan atas penyajian 
data dengan tujuan untuk memperoleh kesimpulan mengenai bentuk miskonsepsi yang dialami siswa dalam menyelesaikan soal bilangan berpangkat. Setelah dianalisis data bentuk miskonsepsi yang dialami siswa pada saat tes, kemudian akan diperoleh data tentang perubahan data miskonsepsi yang dialami siswa dalam menyelesaikan soal bilangan berpangkat.

\section{Hasil dan Pembahasan}

\section{A. Hasil Penelitian}

Dari hasil analisis data ditemukan banyak miskonsepsi yang dialami siswa dalam materi bilangan berpangkat pada soal. Untuk lebih jelasnya peneliti sajikan data hasil analisis berikut:

Tabel 2.

Hasil Analisis Data Siswa pada Soal

\begin{tabular}{lccccccc|}
\hline Bentuk Jawaban & 1 & 2 & 3 & 4 & 5 & 6 & Jumlah \\
\hline $\begin{array}{l}\text { Miskonsepsi } \\
\text { Generalisasi }\end{array}$ & 12 & 8 & 0 & 0 & 0 & 6 & 26 \\
\hline $\begin{array}{l}\text { Miskonsepsi } \\
\text { Notasi }\end{array}$ & 0 & 0 & 0 & 19 & 0 & 0 & 19 \\
\hline $\begin{array}{l}\text { Miskonsepsi } \\
\text { Penspesialisasian }\end{array}$ & 0 & 0 & 0 & 0 & 0 & 0 & 0 \\
\hline $\begin{array}{l}\text { Miskonsepsi } \\
\text { Bahasa }\end{array}$ & 0 & 0 & 27 & 0 & 29 & 0 & 56 \\
\hline Tidak Benar & 0 & 0 & 1 & 1 & 3 & 2 & 7 \\
\hline Benar & 20 & 24 & 4 & 12 & 0 & 24 & 84 \\
\hline
\end{tabular}

Berdasarkan Tabel 2, pada soal nomor satu hanya ditemukan miskonsepsi generalisasi sebanyak 12 siswa dari 32 siswa (37,50\%). Sedangkan, siswa yang mampu menjawab dengan benar sebanyak 20 dari 32 siswa dengan persentase (62,50\%). Dari 12 siswa yang mengalami miskonsepsi generalisasi pada soal nomor satu diantaranya siswa tidak mampu menentukan basis serta eksponennya atau siswa menganggap basis sebagai eksponen dan eksponen sebagai basis. Berikut adalah contoh jawaban siswa yang mengalami miskonsepsi generalisasi pada soal nomor satu.

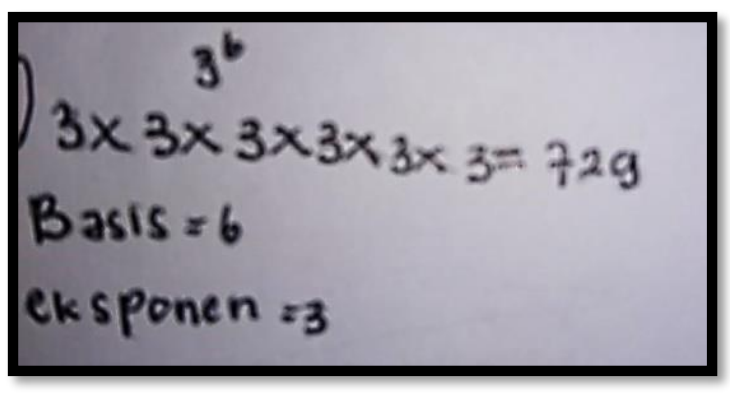

Gambar 2. Jawaban Tertulis S-26 pada Soal Nomor Satu.

Berdasarkan Gambar 2, siswa tidak memahami unsur-unsur dari suatu bentuk bilangan berpangkat sehingga ia menganggap eksponen sebagai basis, dan basis sebagai eksponen.

Untuk soal nomor dua juga ditemukan miskonsepsi generalisasi sebanyak 8 siswa (25,00\%). Sedangkan, siswa yang mampu menjawab dengan benar sebanyak 24 siswa (75,00\%). Berikut adalah contoh jawaban siswa yang mengalami miskonsepsi generalisasi yang dialami siswa pada soal nomor dua.

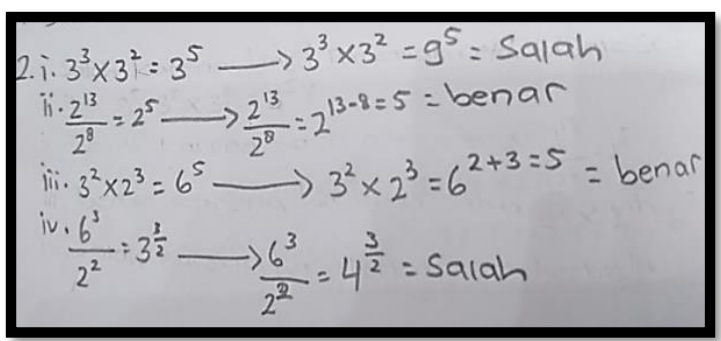

Gambar 3. Jawaban Tertulis S-9 pada Soal Nomor Dua.

Berdasarkan Gambar 3, siswa menganggap bahwa yang sesuai dengan 
sifat perkalian dan pembagian bilangan berpangkat adalah poin ii dan iii. Pada poin i dan iii siswa mengalikan kedua basisnya lalu menjumlahkan eksponennya. Sedangkan pada poin iv siswa mengurangkan kedua basisnya, dan membagi eksponennya. Bentuk miskonsepsi generalisasi yang terjadi pada soal nomor dua diantaranya siswa belum memahami sepenuhnya mengenai metode perkalian dan pembagian bilangan berpangkat.

Untuk soal nomor tiga terdapat miskonsepsi bahasa yang dialami siswa. Jumlah siswa yang mengalami miskonsepsi bahasa sebanyak 27 siswa (84,38\%). 1 siswa (3,13\%) tidak menjawab soal (jawaban siswa kosong), sedangkan 4 siswa lainnya (12,50\%) mampu menjawab soal ini dengan benar. Kebanyakan siswa mengalami miskonsepsi bahasa pada soal ini diantaranya siswa tidak mampu merepresentasikan bentuk bilangan berpangkat $a^{n}$, hal ini terlihat dari banyaknya siswa yang mengubah perkalian berulang tersebut ke dalam bentuk $a^{n} \times b^{m}$. Berikut adalah contoh jawaban siswa yang mengalami miskonsepsi bahasa pada soal nomor tiga bentuk uraian.

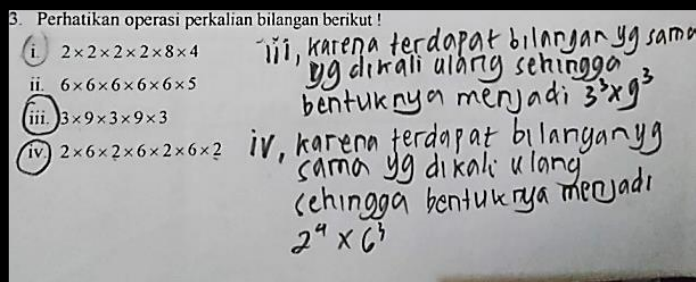

Gambar 4. Jawaban Tertulis S-27 pada Soal Nomor Tiga.
Berdasarkan Gambar 4, siswa tidak dapat merepresentasikan permasalahan yang ada dalam soal, karena siswa mengubah bentuk perkalian tersebut ke dalam bentuk $a^{n} \times b^{m}$, bukan dalam bentuk $a^{n}$.

Selanjutnya untuk soal nomor empat ditemukan 19 siswa (59,38\%) mengalami miskonsepsi notasi, 1 siswa (3,13\%) tidak menjawab dan sisanya 12 siswa $(37,50 \%)$ mampu menjawab soal ini dengan benar. Dari 19 siswa yang mengalami miskonsepsi notasi diantaranya siswa mengabaikan notasi pembagian pada suatu operasi, mengabaikan tanda negatif (-) pada suatu eksponen, mengabaikan nilai eksponen dalam suatu bentuk bilangan berpangkat dan yang lainnya. Berikut peneliti sajikan contoh jawaban siswa yang mengalami miskonsepsi notasi pada soal nomor empat.

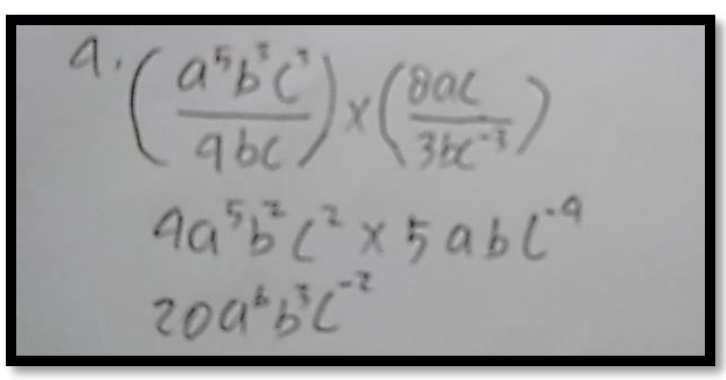

Gambar 5. Jawaban Tertulis S-7 pada Soal Nomor Empat.

Berdasarkan Gambar 5, siswa menyederhanakan $\left(\frac{a^{5} b^{3} c^{3}}{4 b c}\right)$ menjadi $4 a^{5} b^{2} c^{2}$. Siswa mengabaikan tanda pembagian, yang seharusnya jadi $\frac{1}{4}$ siswa menuliskannya 4. Selanjutnya siswa 
menyederhanakan $\left(\frac{8 a c}{3 b c^{-3}}\right) \quad$ menjadi $5 \mathrm{abc}^{-4}$. Siswa menganggap bahwa $\frac{8}{3}$ itu sama saja dengan $8-3=5$ dan mengabaikan lagi tanda pembagian, yang seharusnya $\frac{1}{b}$ siswa menuliskannya $b$. Siswa juga mengaku keliru dalam menyederhanakan $\frac{c}{c^{-3}}=c^{-4}$. Jadi dalam pengerjaan ini siswa banyak mengabaikan notasi pada suatu operasi.

Untuk soal nomor lima, 29 siswa $(90,63 \%)$ mengalami miskonsepsi bahasa, dan sisanya, 3 siswa (9,38\%) tidak menjawab soal ini. Pada soal nomor lima tidak ada satu siswa pun yang mampu menjawab soal ini dengan benar hal ini disebabkan karena banyaknya siswa yang hanya menentukan banyaknya virus tanpa mengilustrasikan pembelahan virus tersebut, sehingga banyak siswa yang mengalami miskonsepsi bahasa. Berikut adalah contoh jawaban siswa yang mengalami miskonsepsi bahasa pada soal nomor lima bentuk uraian.

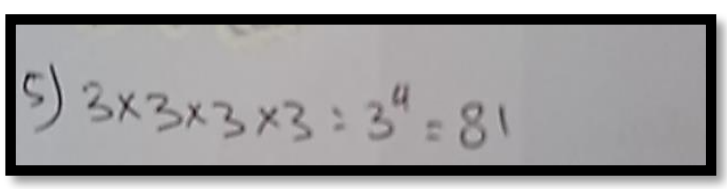

Gambar 6. Jawaban Tertulis S-12 pada Soal Nomor Lima.

Berdasarkan Gambar 6, siswa tidak membuat ilustrasi banyaknya virus setelah 2 jam, melainkan siswa hanya menentukan jumlah virusnya saja. Artinya, siswa tidak dapat merepresentasikan permasalahan yang ada dalam soal.
Untuk soal nomor enam, terdapat 6 siswa (18,75\%) mengalami miskonsepsi generalisasi, 2 siswa (6,25\%) tidak menjawab soal ini, dan sisanya 24 siswa (75,00\%) mampu menjawab soal ini dengan benar. Miskonsepsi generalisasi yang dialami oleh siswa pada soal nomor enam diantaranya siswa tidak mampu menerapkan metode perkalian bilangan berpangkat. Berikut contoh jawaban siswa yang mengalami miskonsepsi generalisasi pada soal nomor enam bentuk uraian.

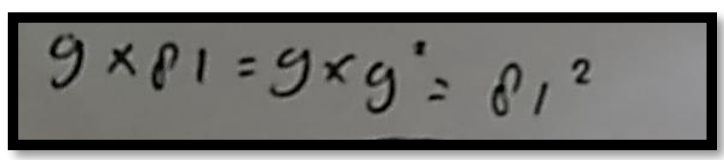

Gambar 7. Jawaban Tertulis S-22 pada Soal Nomor Enam.

Berdasarkan Gambar 7, siswa menyederhanakan bentuk $9 \times 9^{2}$ dengan cara mengalikan basis dengan basis dan eksponen dengan eksponennya atau $9 \times 9^{2}=(9 \times 9)^{2}=81^{2}$.

Secara umum jawaban siswa yang terjadi pada soal bentuk uraian dapat dilihat pada gambar diagram berikut:

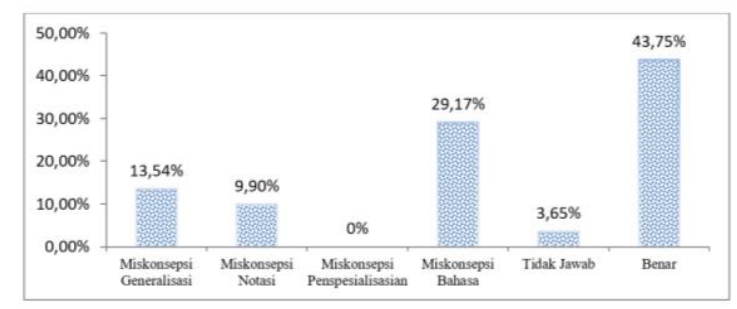

Gambar 8. Data pada Soal.

Berdasarkan Gambar 8, siswa mengalami beberapa bentuk miskonsepsi, diantaranya miskonsepsi generalisasi, miskonsepsi notasi dan miskonsepsi bahasa. Masing-masing persentase dari tiap jenis-jenis miskonsepsi tersebut 
adalah 13,54\%, 9,90\%, dan 29,17\%. Untuk siswa yang tidak menjawab beberapa soal terdapat 3,65\%, sedangkan siswa yang mampu menjawab dengan benar beberapa soal terdapat 43,75\%. Peneliti menyimpulkan bahwa ada lebih dari setengah jumlah siswa mengalami miskonsepsi pada soal (lihat Tabel 3).

Tabel 3.

Rekapitulasi Data Bentuk Miskonsepsi Soal

\begin{tabular}{|c|c|}
\hline Bentuk Jawaban & Persentase Soal \\
\hline Miskonsepsi Generalisasi & $26(13,54 \%)$ \\
\hline Miskonsepsi Notasi & $19(9,9 \%)$ \\
\hline Miskonsepsi Penspesialisasian & $0(0 \%)$ \\
\hline Miskonsepsi Bahasa & $56(29,17 \%)$ \\
\hline Tidak Benar & $7(3,65 \%)$ \\
\hline Benar & $84(43,75 \%)$ \\
\hline Setelah selesai me & Janalisis data, \\
\hline
\end{tabular}

Tabel 4.

Bentuk Miskonsepsi yang Terjadi

\begin{tabular}{|c|c|c|}
\hline $\begin{array}{l}\text { Jenis } \\
\text { Miskonsepsi }\end{array}$ & Indikator Miskonsepsi & Contoh Jawaban Siswa \\
\hline \multirow[t]{8}{*}{ Generalisasi } & $\begin{array}{l}\text { Menganggap eksponen sebagai basis } \\
\text { dan basis sebagai eksponen }\end{array}$ & $\begin{array}{l}3^{6}=3 \times 3 \times 3 \times 3 \times 3 \times 3 \text { Dengan basis } \\
=6 \text {, dan eksponen }=3\end{array}$ \\
\hline & $\begin{array}{l}\text { Menyederhanakan bentuk } a^{n} \times a^{m} \\
\text { menjadi }(a \times a)^{n+m}\end{array}$ & $3^{3} \times 3^{2}=9^{5}$ \\
\hline & $\begin{array}{l}\text { Menyederhanakan bentuk } a^{n} \times a^{m} \\
\text { menjadi }(a \times a)^{n m}\end{array}$ & $9 \times 9^{2}=81^{2}$ \\
\hline & $\begin{array}{c}\text { Menyederhanakan bentuk } a^{n} \times a^{m} \\
\text { menjadi } a^{n m}\end{array}$ & $9 \times 9^{2}=9^{2}$ \\
\hline & $\begin{array}{l}\text { Menyederhanakan bentuk } \\
\qquad a^{n} \times b^{m}=(a \times b)^{n+m}\end{array}$ & $3^{2} \times 2^{3}=6^{5}$ \\
\hline & $\begin{array}{l}\text { Menyederhanakan bentuk } \\
\qquad \frac{a^{m}}{b^{n}}=\left(\frac{a}{b}\right)^{\frac{m}{n}}\end{array}$ & $\frac{6^{3}}{2^{2}}=3^{\frac{3}{2}}$ \\
\hline & $\begin{array}{l}\text { Menyederhanakan bentuk } \\
\qquad a^{n}+a^{m}=(a+a)^{n+m}\end{array}$ & $3^{2}+3^{5}=6^{7}$ \\
\hline & $\begin{array}{c}\text { Tidak dapat mengidentifikasi perkalian } \\
\text { berulang yang dapat diubah ke dalam } \\
\text { bentuk bilangan berpangkat. }\end{array}$ & $\begin{array}{l}2 \times 2 \times 2 \times 2 \times 8 \times 4 \\
\text { Perkalian tersebut tidak dapat diubah ke } \\
\text { dalam bentuk bilangan berpangkat atau } \\
\text { tidak dapat diubah ke dalam bentuk } a^{n}\end{array}$ \\
\hline \multirow[t]{2}{*}{ Notasi } & $\begin{array}{l}\text { Mengabaikan tanda negatif pada } \\
\text { eksponen. }\end{array}$ & $c \times c^{-3}=c^{1+3}=c^{4}$ \\
\hline & $\begin{array}{c}\text { Kesalahan dalam mengoprasikan } \\
\text { penjumlahan ataupun pengurangan } \\
\text { bilangan bertanda positif dan negatif } \\
\text { pada eksponen }\end{array}$ & $c \times c^{-3}=c^{1+(-3)}=c^{-4}$ \\
\hline
\end{tabular}




\begin{tabular}{|c|c|c|}
\hline & $\begin{array}{l}\text { Mengabaikan operasi pembagian dalam } \\
\text { bentuk pecahan atau menganggap } \\
\text { bahwa } \frac{1}{a}=a\end{array}$ & $\left(\frac{a^{5} b^{3} c^{3}}{4 b c}\right)=4 a^{5} b^{2} c^{2}$ \\
\hline & $\begin{array}{l}\text { Mengoprasikan perkalian dengan cara } \\
\text { mengalikan suku pertama dengan } \\
\text { pertama, kedua dengan kedua tanpa } \\
\text { mampu menyederhanakannya }\end{array}$ & $\begin{array}{l}=\left(\frac{a^{5} b^{3} c^{3}}{4 b c}\right) \times\left(\frac{8 a c}{3 b c^{-3}}\right) \\
=\left(\frac{a^{6} b^{3} c^{4}}{4 b^{2} c^{2}}\right) \times\left(\frac{8 a^{1} c^{1}}{3 b^{2} c}\right)\end{array}$ \\
\hline \multirow[t]{2}{*}{ Penspesialisasian } & $\begin{array}{l}\text { Menyederhanakan bentuk } \\
\qquad a^{n}+a^{m}=a^{n+m}\end{array}$ & $3^{2}+3^{5}=3^{7}$ \\
\hline & Menyederhanakan bentuk $\frac{a}{b}=a-b$ & $\frac{8}{3}=8-3=5$ \\
\hline \multirow[t]{2}{*}{ Bahasa } & $\begin{array}{c}\text { Tidak dapat mengilustrasikan } \\
\text { permasalahan nyata yang berkaitan } \\
\text { dengan bilangan berpangkat. }\end{array}$ & $3^{4}=3 \times 3 \times 3 \times 3=81$ \\
\hline & $\begin{array}{c}\text { Merepresentasikan bentuk } a^{n} \text { sama } \\
\text { dengan } a^{n} \times b^{m}\end{array}$ & $\begin{array}{l}\text { Bentuk } a^{n} \text { dari } 3 \times 9 \times 3 \times 9 \times 3 \text { adalah } \\
3^{3} \times 9^{2}\end{array}$ \\
\hline
\end{tabular}

Dari hasil tes pada materi bilangan berpangkat, menunjukkan bahwa masih terdapat siswa yang mengalami miskonsepsi dalam menyelesaikan soal terkait materi bilangan berpangkat. Miskonsepsi yang dialami siswa terdiri dari miskonsepsi generalisasi, miskonsepsi notasi, miskonsepsi penspesialisasian, dan miskonsepsi bahasa.

\section{B. Pembahasan}

1. Miskonsepsi Generalisasi

Pada soal nomor satu, siswa sudah mampu dalam menguraikan bilangan berpangkat menjadi perkalian berulang. Hal ini terlihat dari jawaban siswa yang menganggap basis sebagai eksponen dan eksponen sebagai basis.

Pada soal nomor dua, terdapat bentuk miskonsepsi generalisasi yang telah peneliti duga sebelumnya berkaitan dengan operasi bilangan berpangkat. Miskonsepsi tersebut sejalan dengan hasil penelitian Prabowo (2014) bahwa siswa tidak memahami sifat-sifat bilangan berpangkat, sehingga tidak dapat mengklasifikasikan operasi bilangan berpangkat menurut sifat-sifat yang berlaku.

Pada soal nomor tiga, terdapat bentuk miskonsepsi generalisasi yang telah peneliti duga sebelumnya berkaitan dengan definisi bilangan berpangkat, yaitu tidak dapat mengidentifikasi perkalian berulang yang dapat diubah ke dalam bentuk bilangan berpangkat.

Selanjutnya untuk soal nomor lima, banyak siswa yang tidak mengkaitkan permasalahan yang terdapat dalam soal dengan konsep bilangan berpangkat. 
Pada soal nomor enam, terdapat beberapa bentuk miskonsepsi yang dialami siswa. Menurut Prabowo (2014) hal itu disebabkan oleh ketidakmampuan siswa dalam menyusun algoritma serta kemampuan dalam penggunaan operasi perhitungan sehingga menghasilkan jawaban yang salah.

\section{Miskonsepsi Notasi}

Pada soal nomor empat mengenai mengaitkan berbagai konsep matematika, terdapat miskonsepsi notasi yang telah peneliti duga sebelumnya, diantaranya mengabaikan tanda negatif pada eksponen, kesalahan dalam mengoprasikan penjumlahan ataupun pengurangan bilangan bertanda positif dan negatif pada eksponen, mengabaikan operasi pembagian dalam bentuk pecahan atau menganggap bahwa $\frac{1}{a}=a$, mengoprasikan perkalian dengan cara mengalikan suku pertama dengan pertama, kedua dengan kedua tanpa mampu menyederhanakannya dan mengabaikan nilai eksponen pada suatu bentuk bilangan berpangkat. Dari hasil analisis tersebut peneliti menemukan bentuk miskonsepsi notasi dalam mengoprasikan bilangan berpangkat yang tidak peneliti duga yaitu mengoprasikan perkalian dengan cara mengalikan suku pertama dengan pertama, kedua dengan kedua tanpa mampu menyederhanakannya. Bentuk miskonsepsi ini peneliti kategorikan dalam miskonsepsi notasi karena siswa tidak memahami notasi perkalian sehingga tidak dapat menyederhanakannya hal ini telah dikonfirmasi melalui wawancara siswa yang bersangkutan.

3. Miskonsepsi Penspesialisasian

Menurut Ashlock (Nurtasari, Jamiah, \& Suratman, 2017) menyatakan bahwa miskonsepsi penspesialisasian merupakan bentuk miskonsepsi yang didasari atas spesialisasi yang berlebihan selama proses pembelajaran.

Miskonsepsi penspesialisasian dapat berupa menyamakan suatu konsep dengan konsep lain yang berbeda atau menganggap sebuah konsep dapat digunakan dalam situasi yang berbeda.

Miskonsepsi penspesialisasian banyak terjadi dalam operasi bilangan berpangkat. Peneliti merancang beberapa soal untuk mempermudah peneliti dalam mengidentifikasi miskonsepsi penspesialisasian yang dialami siswa diantaranya soal nomor dua dan enam.

Setelah peneliti menganalisis hasil tes, peneliti menemukan miskonsepsi penspesialisasian pada soal nomor dua. Adapun indikator miskonsepsi penspesialisasiannya yaitu siswa menggunakan konsep perkalian bilangan berpangkat untuk menyelesaikan penjumlahan bilangan berpangkat. Hal ini sejalan dengan hasil penelitian Pinahayu (2015) yang menyatakan bahwa banyak siswa yang menerapkan konsep perkalian bilangan berpangkat pada penjumlahan bilangan berpangkat. 


\section{Miskonsepsi Bahasa}

Wahyuni, Yusmin, \& Suratman (2016), menyebutkan bahwa miskonsepsi bahasa dapat berupa kesalahan dalam mengubah informasi ke dalam bahasa matematika. Miskonsepsi bahasa dalam penelitian ini dibagi menjadi dua subkonsep yaitu miskonsepsi bahasa dalam definisi bilangan berpangkat dan miskonsepsi bahasa pada penerapan konsep bilangan berpangkat.

Miskonsepsi bahasa dalam definisi bilangan berpangkat terjadi pada soal nomor tiga dan nomor lima dimana siswa merepresentasikan bentuk $a^{n}$ sama dengan bentuk $a^{n} \times b^{m}$, sedangkan miskonsepsi bahasa dalam penerapan bilangan berpangkat terjadi pada soal nomor lima yaitu siswa tidak dapat mengilustrasikan permasalahan nyata yang berkaitan dengan bilangan berpangkat.

\section{Penutup}

Hasil dari penelitian ini diharapkan dapat berguna sebagai gambaran terhadap para guru tentang kondisi siswanya ketika mempelajari bilangan berpangkat. Miskonsepsi-miskonsepsi yang terjadi pada penelitian ini diharapkan tidak kembali terjadi pada siswanya. Miskonsepsi-miskonsepsi itu adalah miskonsepsi generalisasi, notasi, penspesialisasian, dan Bahasa. Perlu bagi guru untuk berpikir dalam mencari solusi agar miskonsepsi-miskonsepsi ini tidak terjadi kembali. Bagi peneliti yang akan datang, diharapkan mampu mengembangkan penelitian yang dapat mengatasi miskonsepsi-miskonsepsi yang dialami siswa pada materi bilangan berpangkat ini.

\section{Daftar Pustaka}

Afriansyah, E. A. (2012). Design Research: Konsep Nilai Tempat pada Penjumlahan Bilangan Desimal. Tesis yang tidak dipublikasikan berasal dari Beasiswa DIKTI dengan program IMPoME (International Master Program on Mathematics Education). Universitas Sriwijaya PalembangUniversitas UTRECHT Belanda.

Afriansyah, E. A., \& Dahlan, J. A. (2017). Design Research in Fraction for Prospective Teachers. In 5th SEA-DR (South East Asia Development Research) International Conference 2017 (SEADRIC 2017). Atlantis Press.

Febriyani, V. D. (2015). Analisis Keasalahan Siswa Dalam Menyelesaikan Soal Bilangan Berpangkat Pada Siswa Kelas X SMK Kanisius 1 Pakem Tahun Pembelajaran 2014/2015.

Ikram, R. L., Suharto, S., \& Setiawani, S. (2018). Analisis Miskonsepsi Siswa dalam Menyelesaikan Permasalahan Persamaan Kuadrat Satu Variabel Ditinjau dari Perbedaan Gender. KadikmA, 9(3).

Latifah, U. L. N., Wakhyudin, H., \& Cahyadi, F. (2020). Miskonsepsi Penyelesaian 
Soal Cerita Matematika Materi FPB dan KPK Sekolah Dasar. JRPD (Jurnal Riset Pendidikan Dasar), 3(2), 181195.

Nurtasari, A. R., Jamiah, Y., \& Suratman, D. (2017). Miskonsepsi Siswa pada Materi Himpunan di Kelas VII SMP Santa Monika Kubu Raya. Jurnal Pendidikan dan Pembelajaran Khatulistiwa, 6(2). 1-10.

Pinahayu, E. A. R. (2016). Problematika pembelajaran matematika pada pokok bahasan eksponen dan alternatif pemecahannya. Formatif: Jurnal Ilmiah Pendidikan MIPA, 5(3).

Pratama, A. P. (2017). Analisis Kesalahan Siswa dalam Menyelesaikan Soal Matematika Materi Statistika. EKUIVALEN-Pendidikan Matematika, 28(1).

Sari, H. M., \& Afriansyah, E. A. (2020). Analisis Miskonsepsi Siswa SMP pada Materi Operasi Hitung Bentuk Aljabar. Mosharafa: Jurnal Pendidikan Matematika, 9(3). 439-450.

Siagian, P., \& Surya, E. (2018). Analisis Kesalahan dalam Menyelesaikan Soal Matematika Materi Perpangkatan dan Bentuk Akar.

Sugiyono. (2018). Metode Penelitian Pendidikan Matematika. Bandung: Alfabeta.

Susanti, S. (2020). Upaya Peningkatan Hasil Belajar Matematika Materi Pecahan melalui Pendidikan Matematika Realistik pada Siswa Kelas IV C SD
Negeri 08 Pulau Punjung. Education and Training, 1(2), 122-127.

Utami, R. (2019). Analisis Miskonsepsi Siswa Dan Cara Mengatasinya Pada Materi Bentuk Aljabar Kelas VII-C SMP Negeri 13 Malang. Jurnal Pendidikan Matematika (JPM), 3(1). 37-44.

Wahyuni, T. N., Yusmin, E., \& Suratman, D. (2016). Miskonsepsi Siswa pada Penjumlahan dan Pengurangan Bentuk Akar di Kelas X SMKN 1 Pontianak.Jurnal Pendidikan dan Pembelajaran Khatulistiwa, 5(11). 1$16 .$.

Yanti, R. A. (2017). Analisis kemampuan berpikir aljabar siswa berdasarkan miskonsepsi (Bachelor's thesis, UIN Syarif Hidayatullah Jakarta: Fakultas Ilmu Tarbiyah dan Keguruan).

\section{Riwayat Hidup Penulis}

Puji Nurkamilah, S.Pd.

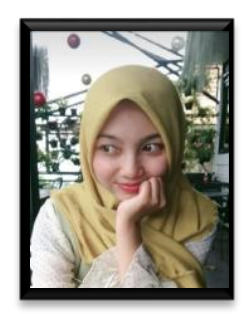

Lahir di Tasikmalaya, 29 Juli 1998. Staf Pengajar di SDIT Bina Insan Qur'ani. Studi S1 Pendidikan Matematika Institut Pendidikan Indonesia, Garut, lulus tahun 2020.

\section{Dr. Ekasatya Aldila Afriansyah, M.Sc.}

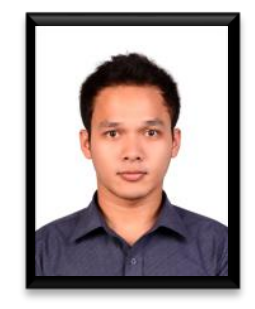
Lahir di Bandung, 4 April 1986. Dosen Tetap Yayasan Institut Pendidikan Indonesia, Garut. Studi S1 Matematika Konsentrasi Statistika UPI, Bandung, lulus tahun 2009; S2 Pendidikan Matematika UNSRIUTRECHT, Palembang-Utrecht, lulus tahun 2012; S3 Pendidikan Matematika UPI, Bandung, lulus tahun 2021. 